Ewa Sobolewska-Poniedziatek

Uniwersytet Zielonogórski

e-mail: e.sobolewska-poniedzialek@wez.uz.zgora.pl

\title{
MENTORING W CROWDSOURCINGU - INNOWACYJNY SPOSÓB NA WYKORZYSTANIE POTENCJAŁU OSÓB STARSZYCH
}

\section{Abstract \\ Mentoring in crowdsourcing as an innovative method of exploiting the potential of the elderly}

The combination of mentoring and crowdsourcing strategy creates new possibilities for solving problems in both, business and social sphere. On the one hand, mentoring is a form of support for the professional development of the organization's employees. On the other hand, it can be seen as a way to exploit the potential of the elderly. This idea corresponds to the goals of crowdsourcing, as a means of supporting the 'crowd' in solving problems. Older people in this situation are a group that has unmistakable counseling potential that can be used in the form of mentoring in crowdsourcing.

Keywords: mentoring, crowdsourcing, the elderly, professional and social potential

\section{Streszczenie}

Połączenie strategii mentoringu i crowdsourcingu stwarza nowe możliwości w zakresie rozwiązywania problemów występujących zarówno w działalności biznesowej, jak i sferze społecznej. Z jednej strony mentoring stanowi formę wsparcia rozwoju zawodowego pracowników organizacji, z drugiej zaś może być traktowany jako sposób wykorzystania potencjału osób starszych. Idea ta koresponduje z celami crowdsourcingu jako metody opartej na wsparciu „tłumu” w rozwiązywaniu problemów. Osoby starsze w tej sytuacji stanowią grupę niewątpliwie dysponującą potencjałem doradczym, który może być wykorzystany w formie mentoringu w działaniach crowdsourcingowych.

Słowa kluczowe: mentoring, crowdsourcing, osoby starsze, potencjał zawodowy i społeczny 


\section{Wstęp}

Rosnąca dynamika starzenia się współczesnych społeczeństw rodzi potrzebę nowego spojrzenia na rolę i znaczenie osób starszych. Konieczność podejmowania działań zmierzających w stronę zagospodarowania potencjału tej grupy wynika nie tylko ze zwiększającego się ich udziału w populacji ogółem, ale wiąże się również z potrzebą zwrócenia uwagi na korzyści z tym związane. Niewątpliwie bowiem rezerwuar społecznych i profesjonalnych kompetencji osób starszych jest znaczący i cenny. Jedną z możliwości wykorzystania zasobów reprezentowanych przez te osoby stwarza mentoring, w swej istocie zakładający, że mentorem jest osoba, która ma zarówno kompetencje, jak i umiejętności wynikające z nabytego doświadczenia. Potencjał drzemiący w osobach starszych może być pożytkowany m.in. przez ich udział w przedsięwzięciach crowdsourcingowych. Crowdsourcing z kolei umożliwia dzielenie się wiedzą i pomysłami rozwiązania konkretnego problemu dzięki doradztwu zarówno specjalistów, jak i niespecjalistów w danej dziedzinie. Liczy się bowiem kreatywność i twórcze podejście do zagadnienia. W niniejszej pracy podjęto próbę analizy możliwości wykorzystania mentoringu w crowdsourcingu w związku z potencjałem reprezentowanym przez osoby starsze. W tym celu zastosowano metodę krytycznej analizy literatury przedmiotu.

\section{Nowe spojrzenie na rolę i znaczenie osób starszych w dobie przemian demograficznych}

Od kilku dekad przedstawiciele wielu dyscyplin naukowych, politycy, decydenci na szczeblu centralnym oraz samorządowym z wielką uwagą przyglądają się procesowi starzenia się ludności. Rosnące zainteresowanie tą problematyką wynika z tego, że wzrost udziału osób starszych w populacji oddziałuje na wszystkie dziedziny życia społeczno-ekonomicznego. W toczącym się dyskursie publicznym na temat procesu starzenia się społeczeństw niezmiennie na plan pierwszy wysuwa się kwestia jego ekonomicznych konsekwencji, co mocno rzutuje na sposób postrzegania osób starszych - często w kategoriach grupy społecznej generującej koszty.

Niemniej jednak nieuchronność kierunku zmian demograficznych oraz konieczność przygotowania się do wyzwań z tym związanych stały się przesłankami do stopniowej reorientacji myślenia o roli seniorów w społeczeństwie i gospodarce.

Pierwszym międzynarodowym dokumentem zawierającym prezentację nowej strategii w tym zakresie był Międzynarodowy plan działania w kwestii starzenia się spoleczeństw, przyjęty w Wiedniu 1982 roku przez Światowe Zgromadzenie na temat Starzenia się Społeczeństw [Międzynarodowy plan..., 2002]. Zwrócono w nim uwagę na kilka kluczowych kwestii. Po pierwsze zaznaczono, że podstawowym celem rozwoju jest ciągła poprawa poziomu życia całej ludności przez pełne uczestnictwo w procesie rozwoju i sprawiedliwy podział korzyści z niego 
płynących. Po drugie zmiany w strukturze wiekowej populacji wpływają w znaczącym stopniu na wzrost gospodarczy, rynek pracy, wielkość i strukturę konsumpcji. Równocześnie podkreślono, że osoby starsze powinny być brane pod uwage jako wartościowe narodowe bogactwo, wnoszące cenny wkład w życie społeczne. Co więcej, integracja międzypokoleniowa powinna pozostać celem rozwoju społeczno-ekonomicznego [Międzynarodowy plan..., 2002]. ONZ zaleca krajom wspieranie pełnego uczestnictwa osób starszych w życiu społecznym i gospodarczym. Seniorzy powinni utrzymywać więzi ze społeczeństwem, brać aktywny udział w formułowaniu i realizacji programów mających wpływ na ich bezpośrednie warunki bytowe. Ważne jest, aby postrzegać osoby starsze w kontekście określonego kapitału: bogatej wiedzy i doświadczenia, którymi seniorzy mogą i powinni się dzielić z młodszym pokoleniem. Aby tak się stało, osoby starsze powinny mieć możliwość poszukiwania i korzystania $\mathrm{z}$ form aktywności na rzecz społeczności, np. pracy jako wolontariusze [Zasady działania ONZ...].

Uznanie kluczowego znaczenia dla społecznego rozwoju międzypokoleniowej współzależności, solidarności i wzajemności stwarza szanse na stopniowe odejście od postrzegania osoby starszej jako sukcesywnie wycofującej się z odgrywanych wcześniej ról społecznych. Faktem jest, że osiągnięcie wieku emerytalnego dla części przedstawicieli tego pokolenia oznacza rzeczywiste wycofanie się z ról stanowiących w istotny sposób o ich pozycji społecznej. Oznacza to niewątpliwą stratę, zarówno dla nich, jak i dla młodego pokolenia. Bezsprzecznie wejście w wiek emerytalny jest trudnym etapem w życiu człowieka, gdyż wiąże się z koniecznością określenia na nowo celu życia. Doświadczenia społeczne i badania prowadzone wśród osób starszych wskazują, że brak aktywności i kontaktów społecznych, poczucie nieprzydatności prowadzą do izolacji, pustki społecznej i osamotnienia. Aktywność przybierająca różne formy traktowana jest zatem jako sposób na ograniczenie postępującego marginalizowania osób starszych we współczesnych społeczeństwach.

Uważa się, że ,aktywizacja musi przebiegać wielokierunkowo, wywierać wpływ na sferę intelektualną i ruchową człowieka $\mathrm{z}$ równoczesnym zapewnieniem mu poczucia bezpieczeństwa i własnej użyteczności oraz życzliwości otoczenia" [Leszczyńska-Rejchert, 2010: 145]. Mówiąc o nowym spojrzeniu na rolę osób starszych w społeczeństwie i gospodarce, warto przywołać cel, jaki przyświecał ustanowieniu Europejskiego Roku Aktywności Osób Starszych i Solidarności Międzypokoleniowej w 2012 roku. Zaznaczano, że jest nim ,ułatwianie tworzenia kultury aktywności osób starszych w Europie w oparciu o zasadę społeczeństwa otwartego na wszystkie grupy wiekowe" [Decyzja Parlamentu Europejskiego i Rady, 2011, art. 2: 246/8]. Potrzeba reorientacji myślenia o aktywności osób starszych w sferze społecznej i zawodowej jest coraz częściej akcentowana w opracowaniach naukowych czy strategiach rozwoju regionów. W kontekście zachodzących zmian demograficznych szczególne znaczenie ma aktywność promująca integrację wewnątrz- i międzypokoleniową.

Dla przynajmniej części seniorów, którzy są gotowi do dzielenia się wolnym czasem, wiedzą, doświadczeniem życiowym i zawodowym, takie pole do aktywności stwarza m.in. mentoring. 


\section{Istota mentoringu — klasyczne i współczesne ujęcie}

Niepewność współczesnego świata sprawia, że wzrasta potrzeba odnowienia partnerskiej relacji mistrz-uczeń. Dynamicznie zmieniające się otoczenie i wysokie tempo życia nie sprzyjają refleksji nad tym, jaką wiedzę posiadamy i czego powinniśmy się jeszcze nauczyć, w konsekwencji często jednostka traci z oczu cel. W tej sytuacji w sposób naturalny wyłania się potrzeba relacji z kimś, kto pomoże ustalić priorytety, nakreśli różne warianty działania, pozostawiając decyzję jednostce. Wydaje się, że mentoring $\mathrm{w}$ dobie społeczeństwa wiedzy, organizacji uczących się oraz dążenia jednostek do rozwoju jest strategią bardzo pomocną, czego potwierdzeniem jest jego rosnąca popularność. Czym zatem on jest?

Na próżno szukać w literaturze przedmiotu uniwersalnej definicji mentoringu, tym bardziej że pojawiają się jego nowe formy. Różnorodność interpretacji wynika m.in. z faktu, że część autorów definiuje go w kategoriach działań „mentora”, pozostali zaś odwołują się do mentoringu jako pewnego procesu.

David Clutterbuck opisuje mentoring jako ,jedną z najskuteczniejszych metod rozwoju, jakie mają do dyspozycji pojedynczy ludzie i organizacje" [za: Parsloe, Wray, 2002: 78]. Gordon Shea uszczegóławia tę interpretację, wskazując, że „mentoring jest relacją nakierowaną na rozwój, opiekę, dzielenie się i pomoc, w której jedna osoba inwestuje swój czas, know-how i energię, żeby pobudzić i przyspieszyć rozwój innej osoby, rozwinąc jej wiedzę oraz zdolności” [Shea, 1995: 3]. Warto podkreślić, że mentoring rozpatrywany jako proces wspomagający rozwój indywidualny jednostki polega na jej wsparciu, wzmocnieniu, nie należy zatem interpretować go w kategoriach procesu kształtowania jednostki według jakiegoś klucza. Sensem mentoringu jest z jednej strony dostarczanie swobody i wolności decyzji, z drugiej zaś umiejętności rozważania wyborów, które mają wpływ na życie jednostki.

Można wyodrębnić kilka podejść do mentoringu jako określonej strategii działania. W podejściu elitarnym mentoring ujmowany jest jako metoda rozwoju kompetencji i transmisji wartości dostępna jedynie niewielkiej grupie najbardziej utalentowanych pracowników. W podejściu egalitarnym mentoring traktuje się jako obowiązkowy standard $\mathrm{w}$ relacji przełożonego z podwładnym. $Z$ kolei w podejściu systemowym mentoring uważany jest za pewną filozofię leżącą u podstaw stosunków międzyludzkich, w konsekwencji jest częścią wartości istotnych $\mathrm{w}$ danej organizacji. Z uwagi na to, że mentoring ukierunkowany jest na wspieranie jednostki podczas rozwijania kompetencji, realizacji jej ścieżki zawodowej w dłuższym horyzoncie czasowym, mentorem zostaje zwykle osoba o zdecydowanie większym bagażu doświadczeń i wiedzy. Celem mentoringu jest najczęściej wsparcie w przekształcaniu wiedzy, rezultatów pracy i/lub sposobu myślenia jednostki. Mentoring może przybierać postać zarówno nieformalnej relacji, jak i sformalizowanego programu [Czekaj, 2007: 48-53].

Tradycyjny model mentoringu opiera się na relacji między mentee (uczniem) a mentorem, co powoduje, że jego skuteczność w dużej mierze zależy od siły więzi, 
jaka wytwarza się między tymi podmiotami. Niewątpliwą zaletą tradycyjnej formuły mentoringu jest umożliwienie budowy głębokich relacji, co może przyspieszyć rozwój mentee. W modelu tym pojawiają się jednak pewne ograniczenia, jak chociażby niewielka liczba mentorów, brak odpowiedniego przygotowania osób do roli mentora, brak czasu itp. Dodatkowo zwraca się uwagę, że tradycyjne programy mentoringu, często przeznaczone dla nielicznych, są postrzegane jako niesprawiedliwe społecznie.

Nowoczesne podejście do mentoringu opiera się na budowaniu sieci relacji. Wychodzi się z założenia, że w procesie rozwoju jednostki pomocna jest wiedza i doświadczenie przekazywane w organizacji nie tylko z góry na dół oraz z dołu do góry, ale również uczenie się od siebie nawzajem. Zaletą takiego podejścia jest możliwość zaangażowania w mentoring większej liczby osób, jak również wykorzystanie różnych metod i narzędzi.

Zasadnicza różnica między tradycyjnym a nowoczesnym modelem mentoringu sprowadza się do tego, że relacja jeden do jednego jest zastępowana budowaniem bardzo wielu relacji z wieloma ludźmi jednocześnie, zaś celem mentoringu jest wzajemne uczenie się przez współpracę w ramach sieci biznesowych relacji. Mentoring ewoluuje pod wpływem rozwoju nowych technologii, które dają możliwość wzajemnego uczenia się m.in. przez wykorzystywanie telekonferencji, poczty elektronicznej itp. Zastosowanie tych narzędzi przyczyniło się do powstania nowej formy mentoringu określanej jako e-mentoring [Sołtys, Tarkowska, 2008]. Jego rosnąca popularność wynika z dużego komfortu i łatwości nawiązywania nowych kontaktów i ich dalszego utrzymywania - nie są bowiem konieczne bezpośrednie spotkania, nie ma ograniczeń geograficznych i czasowych [Karwala, 2009]. Wiele organizacji dostrzega tę szansę rozszerzenia programów mentoringu przez wykorzystanie e-mentoringu, umożliwiającego dotarcie do większej liczby uczestników.

Nowe technologie uprościły implementację mentoringu, a także umożliwiły realizację projektów na znacznie większą skalę. Obecnie najbardziej rozwinięta sieć międzynarodowego programu e-mentoringowego jest dostępna w ramach platformy internetowej MentorNet, będącej projektem non profit [MentorNet]. Platforma ta umożliwia rejestrację nowych członków i w pełni zautomatyzowany proces dopasowywania ucznia do mistrza. Program e-mentoringu trwa osiem miesięcy i w tym okresie mentee jest wspierany przez swojego mentora, a ponadto może korzystać ze szkoleń dostępnych na platformie oraz przez e-mail, a także forów i baz wiedzy. Jak wspomniano wcześniej, jednym z wyzwań związanych $\mathrm{z}$ mentoringiem twarzą $\mathrm{w}$ twarz jest udostępnienie czasu, zwłaszcza w sytuacji, gdy osoby zaangażowane w mentoring nie pracują bądź nie mieszkają w tym samym miejscu. W tej sytuacji e-mentoring jest korzystną formą współpracy, gdyż oferuje możliwość pozostania w kontakcie niezależnie od odległości fizycznej między osobami. 


\section{Crowdsourcing jako innowacyjna metoda rozwiązywania problemów}

Mądrość, wiedza, doświadczenie, umiejętności, instynkt czy talent są cechami, które w pewnym stopniu dotyczą każdego człowieka. Co jednak dzieje się w sytuacji, gdy tego rodzaju cechy reprezentowane są przez wiele osób, które jednocześnie pełnią funkcję doradczą? Może to wpływać na powstanie chaosu i zamieszania, ale może też otwierać niezwykłe wręcz możliwości rozwiązywania problemów z wykorzystaniem potencjału „tłumu”. „Mądrość tłumu” - w taki sposób tłumaczona jest istota crowdsourcingu. Ta metoda rozwiązywania problemów zyskuje coraz bardziej na popularności. Kreatywność, stojąca za udzielającymi rad, i ich dystans do firmy czy problemu mogą być znaczącą wartością dodaną tej metody.

Termin „crowdsourcing” został po raz pierwszy użyty przez Jeffa Howe'a na łamach czasopisma „Wired Magazine” w 2006 roku. Cała idea crowdsourcingu opiera się na założeniu, że „wiedza tłumu” może stać się jednym z kluczowych czynników pomocnych w realizacji części zadań, które dotychczas były wykonywane przez pracowników firmy. Miejscem zetknięcia się z działaniami crowdsourcingowymi są sieci internetowe, zaś w szczególności portale społecznościowe lub portale specjalnie tworzone przez firmy zrzeszające użytkowników [Krawiec, 2014: 15]. Enrique Estellés-Arolas i Fernando González-Ladrón-de-Guevara [2012: 189-190] rozumieją crowdsourcing jako „rodzaj aktywności uczestniczącej wykonywanej online, w której indywidualne osoby, instytucje, organizacje non profit lub przedsiębiorstwa proponują dobrowolne uczestnictwo w rozwiązaniu problemu osobom o różnej wiedzy i doświadczeniu"'. Z kolei Frank Kleemann i in. [2008: 22] piszą, że crowdsourcing ,jest formą włączania użytkowników lub konsumentów w wewnętrzne procesy tworzenia wartości. Istotą crowdsourcingu jest zamierzona mobilizacja do komercyjnego wykorzystywania twórczych pomysłów i innych form stworzonych przez konsumentów". Omar Alonso i Matthew Lease [2011: 1] definiują crowdsourcing jako swoisty outsourcing zadań skierowany do dużej grupy osób z zewnątrz zamiast zlecania rozwiązania tych zadań pracownikom lub kontrahentom. Daren Brabham [2013: 3] do kluczowych składników crowdsourcingu zalicza:

1) organizację, która ma zadanie do wykonania,

2) społeczność gotową wykonać to zadanie dobrowolnie,

3) środowisko online, które umożliwia pracę, oraz społeczność, która współdziała z organizacją,

4) wzajemne korzyści dla organizacji i społeczności.

Crowdsourcing jest metodą nieustrukturyzowaną, niehierarchiczną, cechującą się dużym zindywidualizowaniem. Ma także wiele cech ogólnego chaosu oraz otwartości na zasoby zewnętrzne. Wyzwala to oryginalność i indywidualność,

1 Tu i niżej przekład własny. 
umożliwia porzucenie schematów, uprzedzeń i wykorzystanie wielu płaszczyzn do obserwacji problemu i zaproponowania jego rozwiązania. Przewagą crowdsourcingu jest też potencjalnie duża liczba uczestników, którzy także mogą zostać włączeni w udział w projekcie, co uzależnione jest od uruchomienia czynników motywacyjnych [Skawińska i in., 2014: 359].

Metoda ta oparta jest na wykorzystaniu nowoczesnych środków komunikacji, w tym portali społecznościowych, których wpływ i oddziaływanie mają niespotykaną jak dotąd skalę. Łatwość dostępu do internetu i coraz większa chęć zaistnienia mogą być dodatkowymi czynnikami wzmacniającymi popularność crowdsourcingu. W dobie nasyconego rynku i nasilonej walki konkurencyjnej rozwiązania wykorzystujące pomysły ludzi niezwiązanych z branżą/firmą mogą być jeszcze ciekawsze dzięki innemu, zewnętrznemu podejściu do problemu. Niewymuszona kreatywność może prowadzić do innowacyjnych rozwiązań dylematu.

Z perspektywy organizacji poszukującej odpowiedzi na nurtujące pytania wykorzystanie crowdsourcingu może być podyktowane m.in. następującymi czynnikami:

1) brakiem wiedzy na temat niezaspokojonych potrzeb społecznych, co wpływa na chęć ich rozpoznania, poznania opinii, poszukiwania doradców,

2) istnieją pomysły dotyczące możliwych sposobów rozwiązania dylematu, ale poszukiwane są opinie, na których podstawie zostanie podjęta decyzja,

3) pojawieniem się w trakcie realizacji procesu innowacyjnego przeszkód, których pokonanie wymaga znalezienia metody służącej rozwiązaniu [Skawińska, Zalewski, 2014].

Mimo że crawdsourcing nie jest nowym zjawiskiem, bo producenci od zawsze starali się poznać opinię konsumentów oraz determinanty popytu na wytwarzane przez nich dobra, to jednak forma pozyskiwania informacji charakterystyczna dla tej metody rozwiązywania problemów stanowi o jej nowatorskim charakterze. Odwoływanie się do opinii i sugestii „tłumu” może mieć formę panelową, czyli być powtarzalne, a opiniodawcy stali. Z marketingowego punktu widzenia stosowanie tej metody może przynieść wymierne korzyści. Jedną z nich jest publicity, wynikająca z częstego nagłaśniania tego typu działań. Poza tym podmiot pytający o opinię odbiorców może być postrzegany jako rzeczywiście liczący się z ich potrzebami, preferencjami i oczekiwaniami.

Ekonomia tłumu w ujęciu Seana Moffitta to obecnie 14 segmentów. Według niego crowdsourcing to m.in. mądrość tłumu, otwarta innowacja, mikrotasking, współtworzenie, crowdfunding, crowd currencies (alternatywne systemy monetarne), społeczności internetowe oraz obszar citizensourcingu (angażowania mieszkańców miast przez samorząd). Wszystkie obszary łączy angażowanie społeczności przez rozwiązania technologiczne (platformy internetowe) oraz przejrzystość działania [za: Kasprzycki-Rosikoń, 2015].

Bill Joy z Sun Microsystems powiedział kiedyś: „Niezależnie kim jesteś, większość mądrych ludzi pracuje dla kogoś innego" [za: Kasprzycki-Rosikoń, 2015]. Crowdsourcing umożliwia dotarcie do źródeł wiedzy, kreatywności i potencjału drzemiącego w zasobach, które leżą także poza organizacją. Tym potencjałem mogą być konsumenci, rozproszeni po świecie eksperci, studenci czy matki 
przebywające na urlopie macierzyńskim oraz osoby na emeryturze. Dzięki wykorzystaniu ich potencjału firma zyskuje możliwość zwiększenia swoich szans na uzyskanie przewagi konkurencyjnej [Kasprzycki-Rosikoń, 2015]. Ponadto pewne elementy crowdsourcingu opierające się na posługiwaniu się wiedzą anonimowego tłumu mogą przyczynić się do zwiększenia efektywności zatrudnionych pracowników zgodnie z zasadami konkurencji [Kinal, 2017: 120].

Crowdsourcing może być wykorzystywany zarówno w działalności biznesowej, jak i niekomercyjnej. Jest on na tyle elastycznym zjawiskiem, że może znaleźć zastosowanie w wielu sferach działalności: $\mathrm{w}$ akcjach społecznych, samorządowych czy stricte komercyjnych [Kowalska, 2016: 164]. Może być opłacany, np. w formie fundowanych nagród czy innego wynagrodzenia dla autora wybranego pomysłu, jak i mieć charakter wolontariacki. Ze względu na to, że historia rozwoju tej metody pozyskiwania pomysłów nie jest długa, istniejące rozwiązania nie doczekały się ani konkretnych regulacji prawnych, ani też ujednoliconego sposobu postępowania w ramach przedsięwzięcia crowdsourcingowego.

Ciekawym polem zastosowania crowdsourcingu może być rozwój innowacji społecznych oparty na wykorzystaniu zasobów ludzkich w poszukiwaniu nowych rozwiązań problemów społecznych, w tym także z wykorzystaniem potencjału twórczego osób, które potrzebują tych rozwiązań.

\section{Korzyści płynące z wykorzystania potencjału osób starszych jako mentorów w procesie crowdsourcingu}

Potencjał kreatywny osób biorących udział w przedsięwzięciach crowdsourcingowych może być niezwykle cenny, nawet wtedy gdy z pozoru wydaje się, że rozwiązanie danego problemu nie leży w czyichś kompetencjach. Liczy się bowiem nie tylko wiedza na dany temat, ale także pomysłowość, nietuzinkowe rozwiązania i świeże spojrzenie oczami niespecjalisty. Zatem każdy może mieć swój udział w rozwoju przedsięwzięć. Jeśli w taki sposób traktować potencjał twórczy „tłumu”, to wydaje się, że osoby starsze mogą być w tym obszarze bardzo przydatne - z racji m.in. życiowego doświadczenia i kompetencji oraz mądrości nabywanych wraz z wiekiem.

Mentor w sposób bezpośredni kojarzy się z osobą dojrzałą, zarówno pod względem doświadczenia, wiedzy, jak i wieku. Osoby starsze jako mentorzy mogą cechować się i jednym, i drugim, co często przekłada się na trafność wsparcia merytorycznego z ich strony. Wyposażeni w bardzo cenne we współczesnym świecie zasoby, takie jak czas, doświadczenie i dyspozycyjność, stają się niezwykle wartościową grupą. Jeśli zestawić to dodatkowo z demograficznymi przeobrażeniami, $w$ tym z przybierającym na sile procesem starzenia się społeczeństw, to można zauważyć co najmniej dwie szanse wynikające $\mathrm{z}$ tego połączenia. $Z$ jednej strony $z$ racji wzrostu odsetka osób starszych wzrastają także możliwości skorzystania $\mathrm{z}$ charakteryzującego je potencjału. $Z$ drugiej strony przeobrażenia w strukturze wieku wpływają również na przeobrażenia 
na rynku. Zatem opinie, poglądy, wiedza na temat potrzeb tej grupy mogą być traktowane jako kapitał służący rozwojowi branż i segmentów rynku ukierunkowanych m.in. na zaspokajanie potrzeb osób starszych. Korzyści dla nich jako mentorów i twórców rozwiązań mogą obok materialnej przybierać także formę pozafinansową. Kryzys relacji rodzinnych, międzypokoleniowych, czy szerzej społecznych, prowadzi do tego, że w szczególności osoby spoza grupy aktywnych zawodowo zmagają się z wykluczeniem społecznym. Udział w projektach crowdsourcingowych mógłby być postrzegany jako sposób przeciwdziałania tym zjawiskom i stymulować dłuższą aktywność zarówno zawodową, jak i społeczną. Takie konsekwencje byłyby z ekonomicznego i społecznego punktu widzenia wartościowe i pożądane. Powszechnie bowiem wiadomo, że możliwość koncentracji na pomocy innym sprzyja poprawie samopoczucia, a to indukuje wzrost chęci do życia i działania.

Na rysunku 1 zaprezentowano przykładowe korzyści wynikające z zastosowania mentoringu w organizacji $\mathrm{w}$ ramach procesu crowdsourcingu. Można do nich zaliczyć:

1) rozwój zasobów ludzkich, możliwy dzięki wsparciu indywidualnego rozwoju zawodowego pracowników, co sprzyja podniesieniu efektywności działania firmy;

2) transfer wiedzy i umiejętności od bardziej doświadczonych pracowników w danej branży, firmie bądź na danym stanowisku;

3) budowę pozytywnych więzi w firmie;

4) pobudzenie potencjału drzemiącego w jednostce, zwiększenie efektywności działania.

Z kolei mentorzy gotowi poświęcić swoją energię i czas na wsparcie osób młodych zyskują szanse na dłuższą aktywność społeczno-zawodową.

Inicjatywy, które umożliwiają osobom starszym partycypowanie w życiu społecznym i zawodowym, cieszą się dużym zainteresowaniem. Mentoringowe wsparcie samorządów w postaci tzw. rad seniorów może tu być doskonałym przykładem czerpania $\mathrm{z}$ ich doświadczenia i życiowej mądrości starszych. Innym rozwijającym się pomysłem jest tzw. obywatelskie dziennikarstwo, które może być źródłem aktywności osób starszych w roli i dziennikarzy, i czytelników. Jako przykład może także posłużyć sieć uniwersytetów trzeciego wieku, których według danych z portalu senior.pl było w 2017 roku ok. 411. Świadczy to o potrzebie aktywności i poszukiwaniach inicjatyw, w ramach których można kreatywnie i pożytecznie spędzić czas. Dobry przykład stanowią też inicjatywy znane jako bank czasu, pozwalające osobom starszym oferować swoją pomoc, ale także liczyć na wzajemność ze strony innych użytkowników.

Warto również pamiętać o tym, że udział seniorów w różnego rodzaju projektach będzie możliwy tylko wtedy, gdy oni sami będą tym zainteresowani. Wykluczenie ich z życia zawodowego i społecznego to jeden problem, drugim jest tzw. autodyskryminacja, która wynikać może z jednej strony z chęci jak najszybszego przejścia $\mathrm{w}$ okres bierności zawodowej, ale $\mathrm{z}$ drugiej z konsekwentnie przez lata kształtowanego obrazu braku akceptacji dla aktywności zawodowej starszych pracowników [Kubicki, 2011]. 


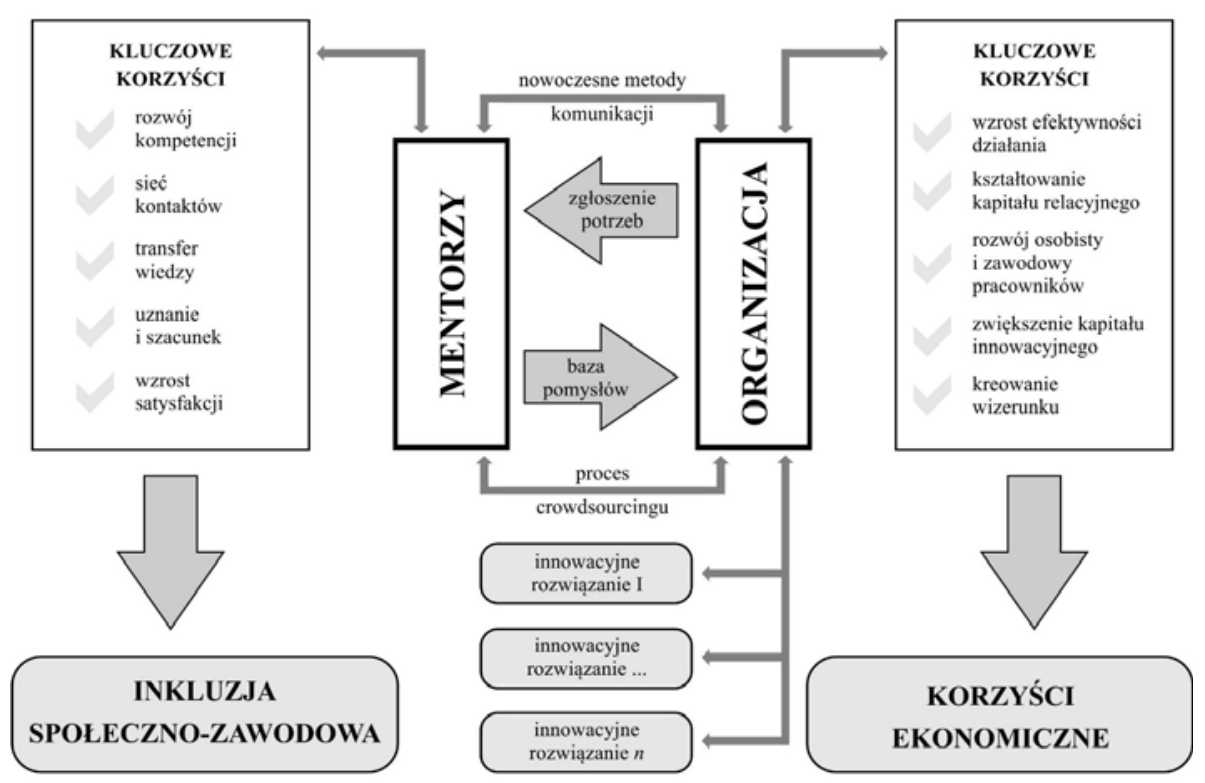

Rysunek 1. Relacje mentorzy-organizacja i korzyści z tym związane

Źródło: opracowanie własne.

\section{Podsumowanie}

U podstaw rozważań zawartych w niniejszym artykule znalazło się przekonanie, że połączenie strategii mentoringu i crowdsourcingu stwarza nowe możliwości w zakresie rozwiązywania problemów występujących zarówno w działalności biznesowej, jak i w sferze społecznej. Pozytywne następstwa zastosowania idei mentoringu w działalności crowdsourcingowej związane są z wysokim poziomem kapitału społecznego, wiedzą i doświadczeniem osób starszych. Mentoring stwarza możliwości ukierunkowania i wsparcia rozwoju zawodowego pracowników organizacji. Może być traktowany również jako sposób na poprawę sytuacji społeczno-zawodowej osób starszych. Dodatkowo dostęp do nowoczesnych technologii w połączeniu z umiejętnościami korzystania z nich przez osoby starsze zapewnia okoliczności sprzyjające innowacyjnemu podejściu do rozwiązywania problemów dzięki kompetencjom tych osób.

Pewnym ograniczeniem w realizacji takiej wizji może być niedostateczny poziom kompetencji informatycznych i cyfrowych osób starszych. Jednakże jak wynika z danych GUS (2017: 110, 125), w ostatnich latach w Polsce odnotowano znaczący wzrost udziału osób w wieku od 55 do 64 lat w populacji korzystających z komputera i internetu. Można zatem zaryzykować tezę, że mentoring może 
być w szerszym zakresie realizowany również w działalności crowdsourcingowej wykorzystującej nowoczesne rozwiązania technologiczne.

Mentoring odgrywa coraz większą rolę w procesach szkolenia, rozwoju i wzbogacania kompetencji specjalistów pracujących w zawodach i spełniających funkcje polegające na pracy z ludźmi. Stąd też rośnie popularność platform mentoringowych The CASE e-Mentoring Platformm i MentorNet, które dają szanse na nawiązanie wirtualnego kontaktu z profesjonalistami w wielu dziedzinach. Platformy online umożliwiają poznanie wielu mentorów, a także zaplanowanie czasu na czat online lub rozmowę telefoniczną. Niewątpliwą zaletą tego typu rozwiązań jest właśnie to, że nie wymagają osobistego kontaktu, trzymania się sztywno wyznaczonych godzin oraz pozwalają na pracę koncepcyjną, ukierunkowaną na indywidualizację, zarówno w odniesieniu do rozwiązywanego problemu, jak i sposobu pracy. Podczas gdy klasyczny mentoring jest związany z relacją jeden do jednego, internet pozwala na komunikację grupową i zachęca do niej, umożliwia kontakt i wymianę informacji ze specjalistycznymi społecznościami i wieloma mentorami. Stąd też e-mentoring oferuje możliwości, których nie daje mentoring twarzą w twarz.

\section{Bibliografia}

Alonso O., Lease M. (2011), Crowdsourcing 101: Putting the WSDM of Crowds to Work for You [w:] WSDM '11: Proceedings of the Fourth ACM International Conference on Web Search and Data Mining, February 9-12, 2011, Hong Kong, China, ACM Press, New York.

Brabham D.C. (2013), Crowdsourcing, The MIT Press, Cambrigde (Mass.)-London.

Czekaj J. (red.) (2007), Metody organizacji i zarzqdzania, Wydawnictwo Akademii Ekonomicznej, Kraków.

Decyzja Parlamentu Europejskiego i Rady nr 940/2011/UE z dnia 14 września 2011 r. w sprawie Europejskiego Roku Aktywności Osób Starszych i Solidarności Międzypokoleniowej (2012), Dziennik Urzędowy Unii Europejskiej z 23.09.2011, L 246/5-L246/10.

Estellés-Arolas E., González-Ladrón-de-Guevara F. (2012), Towards an Integrated Crowdsourcing Definition, „Journal of Information Science” 38(2).

GUS (2017), Społeczeństwo informacyjne w Polsce. Wyniki badań statystycznych z lat 20132017, Warszawa-Szczecin.

Karwala S. (2009), Mentoring jako strategia wspierająca wszechstronny rozwój społeczny [praca magisterska], Wyższa Szkoła Biznesu - National Louis University, Nowy Sącz, http://repozytorium.wsb-nlu.edu.pl/handle/11199/798 [dostęp: 10.10.2017].

Kasprzycki-Rosikoń J. (2015), Perspektywy rozwoju crowdsourcingu [w:] F. Milewski (red.), Ttum jako źródto wiedzy i kapitału, PARP, Warszawa, https://www.parp.gov.pl/images/ PARP_publications/pdf/2015_tlum_jako_zrodlo_wiedzy_i_kapitalu_v_3_0ps.pdf [dostęp: 9.10.2017].

Kinal J. (2017), Crowdsourcing - próba deskrypcji zjawiska, „UR Journal of Humanities and Social Sciences", 1(2). 
Kleemann F., Voß G.G., Rieder K. (2008), Un(der)paid Innovators: The Commercial Utilization of Consumer Work Through Crowdsourcing, ,Science, Technology \& Innovation Studies", 4(1).

Kowalska M. (2016), Crowdsourcing jako proces poszukiwania kreatywnych rozwiqzań [w:] K. Mazurek-Łopacińska, M. Sobocińska (red.), Badania marketingowe - zmiany w metodologii i technikach badawczych, Prace Naukowe Uniwersytetu Ekonomicznego we Wrocławiu, nr 459, Wydawnictwo Uniwersytetu Ekonomicznego, Wrocław.

Krawiec W. (2014), Crowdsourcing - czynniki motywujace tlum do działania, „Marketing i Rynek", 4.

Kubicki P. (2011), Ubóstwo i wykluczenie społeczne osób starszych [w:] R. Szarfenberg (red.), Ubóstwo i wykluczenie społeczne w Polsce, Polski Raport Social Watch, 2010, Kampania Przeciw Homofobii, Warszawa.

Leszczyńska-Rejchert A. (2010), Człowiek starszy i jego wspomaganie. W stronę pedagogiki starości, Wydawnictwo Uniwersytetu Warmińsko-Mazurskiego, Olsztyn.

MentorNet, MentorNet's One-on-One E-mentoring program, http://mentornet.org/organization/programs.html [dostęp: 15.10.2017].

Międzynarodowy plan działania w kwestii starzenia się społeczeństw (2002), Madryt, http:// www.unic.un.org.pl/ageing/plan.php [dostęp: 15.10.2017].

Parsloe E., Wray M. (2002), Trener i mentor. Udziat coachingu i mentoringu $w$ doskonaleniu procesu uczenia się, [tłum. W. Bobiński], Oficyna Ekonomiczna, Kraków.

Shea G. (1995), Can a Supervisor Mentor?, „Supervision”, 56(11).

Skawińska E., Zalewski R.I. (2014), Innowacje społeczne w kontekście inteligentnego rozwoju regionów [w:] J. Wyrwa (red.), Innowacje społeczne w teorii i praktyce, Polskie Wydawnictwo Ekonomiczne, Warszawa.

Skawińska E., Zalewski R.I., Sobolewska-Poniedziałek E. (2014), Crowdsourcing jako metoda generowania i eksploracji innowacji społecznych $w$ Polsce, „Przedsiębiorczość i Zarządzanie”, 15(8), cz. 1: A. Piekutowska, E. Rollnik-Sadowska (red.), Wybrane problemy zarzqdzania rozwojem regionalnym.

Sołtys A., Tarkowska M. (2008), Mentoring w praktyce. Ścieżka kształcenia mentorów i peer-mentorów dla grup defaworyzowanych, Społeczna Wyższa Szkoła Przedsiębiorczości i Zarządzania w Łodzi, Łódź.

Zasady działania ONZ na rzecz osób starszych, http://www.unic.un.org.pl/rozwoj_spoleczny/ age1.pdf [dostęp: 15.10.2017].

senior.pl, http://www.senior.pl/uniwersytety/search.php [dostęp: 15.10.2017]. 